\title{
CZY JESTEŚMY ,SPOŁECZEŃSTWEM HONORU”? REKONSTRUKCJA POJĘCIA HONORU W WYBRANYCH ORZECZENIACH POLSKICH SĄDÓW
}

\section{WPROWADZENIE}

Pojęcie „honor” ślenia takie jak „słowo honoru”, „honorowe zachowanie”, „człowiek bez honoru" można odnaleźć zarówno w literaturze sprzed wieków³, jak i w potocznej mowie czy codziennych publikacjach prasowych. W wielu tekstach poruszających tematykę omawianego pojęcia w kontekście prawa honor jest ukazywany jako wytyczna właściwego postępowania, którego naruszenie wiąże się z określoną sankcją społeczna, lub jako nadrzędna wartość wymagająca ochrony, np. w formie samosądu ${ }^{4}$. Dla podkreślenia znaczenia honoru niektórzy autorzy posługuja się nawet terminem „społeczeństwa honoru” (ang. honour societies $)^{5}$, a więc takich społeczności, w których honor odgrywa szczególną rolę jako główne narzędzie regulacji stosunków społecznych.

Często honour societies, jako społeczeństwa tradycyjne, sa przeciwstawiane społeczeństwom zmodernizowanym ${ }^{6}$, w których - zdaniem autorów - honor stracił swoje nadrzędne znaczenie, ustępując miejsca innym narzędziom regu-

${ }^{1}$ Zagadnienie definicji honoru jest omówione w dalszej części artykułu.

${ }^{2}$ J. Cambell, The Greek hero, w: J.G. Peristiany, J. Pitt-Rivers (eds.), Honor and Grace in Anthropology, (eds.), CUP, Cambridge 1992, s. 129-150.

${ }^{3}$ Honor i honorowe zachowanie były motywem takich wielkich dzieł, jak: Iliada Homera, Pieśń o Rolandzie, Hamlet Williama Szekspira, Konrad Wallenrod Adama Mickiewicza.

${ }^{4}$ Przykładowo: L. Welchman, S. Hossain (eds.), 'Honour': Crimes, Paradigms, and Violence Against Women, Zed Books, London 2005; M. Cooney, Warriors and Peacemakers: How Third Parties Shape Violence, NYU Press, New York 1998; J. Janssen, Your Honour of Your Life? An Exploration of Honour Cases for Police Officers and Other Professionals, Stapel \& De Koning, The Hague 2009.

${ }^{5}$ Ang. społeczności honoru. W literaturze można odnaleźć również inne określenia - honour cultures (kultury honoru) albo honour worlds (światy honoru). Szerzej: M. Cooney, op. cit.; A. Appiah, The Honor Code: How Moral Revolutions Happen, W.W. Norton \& Company, New YorkLondon 2010; A. Gill, Reconfiguring 'Honour'-Based Violence as a Form of Gendered Violence, w: M.M. Idriss, T. Abbas (eds.), Honour, Violence, Women and Islam, Routledge, London 2011; R. Nisbett, D. Cohen, Culture of Honor: The Psychology of Violence in the South, Westview Press, Boulder, Colo., 1996.

${ }^{6}$ Przykładowo: V. Baxter, A.V. Margavio, Honor, self and social reproduction, „Journal for the Theory of Social Behaviour" 41(2), 2010, s. 126. 
lacji stosunków społecznych, np. prawu, albo pojęciu godności ${ }^{7}$. Często z takim stanowiskiem powiązana jest teza, że honor pełni szczególną rolę w tych społecznościach, w których brakuje silnej władzy centralnej8.

Powstaje jednak pytanie, czy oparcie podziału między społeczeństwami zmodernizowanymi i tradycyjnymi na przeciwstawieniu prawa i honoru jako głównych narzędzi regulacji stosunków społecznych, będące podstawą omawianych koncepcji, jest zasadne. Czy rzeczywiście w społeczeństwach, w których głównym regulatorem stosunków społecznych jest prawo, honor stracił swoje znaczenie? A może ta problematyka jest znacznie bardziej skomplikowana? Wreszcie - jaką rolę pełni honor w polskiej kulturze prawnej?

Problem ten jest niezwykle złożony i wymaga wielowątkowej, pogłębionej analizy. Z racji tego, że niniejszy artykuł ma charakter przyczynku do dalszej dyskusji, poniższe rozważania zostaną ograniczone do konkretnego problemu - rekonstrukcji pojęcia honoru w orzecznictwie polskich sądów. W dalszej części artykułu udzielę odpowiedzi na następujące pytania: czy w orzecznictwie polskich sądów występuje termin „honor”? Jeżeli tak, to w jaki sposób jest definiowany? Jakie przepisy prawne zawieraja to pojęcie?

Objęcie zakresem badań orzecznictwa polskich sądów pozwoli nie tylko na wytypowanie przepisów prawnych, odnoszących się (rzeczywiście lub potencjalnie) do honoru, lecz także na wskazanie sposobu ujmowania omawianego pojęcia przez strony postępowań sądowych oraz sędziów ${ }^{9}$. W artykule omówiono wybrane orzeczenia polskich sądów, zarówno powszechnych, jak i administracyjnych, wszystkich szczebli, nieograniczonych terytorialnie do obszaru właściwości określonej apelacji lub województwa ${ }^{10}$. W ramach wstępnych badań przeanalizowano 75 wyroków wraz z uzasadnieniami. Kluczem doboru było występowanie w uzasadnieniu orzeczenia słowa „honor” lub jego odmiany (np. „honorowe”, „bez honoru”, „z honorem”). Omówione poniżej orzeczenia nie wyczerpują całości przeanalizowanego materiału, jednakże ze względu na obszerność tematyki pominięto te wyroki, w których honor - w różnych konfiguracjach - pełnił rolę jedynie incydentalna, pozostając bez znaczenia dla stanu faktycznego, przebiegu sprawy lub wydanego rozstrzygnięcia, a także takie orzeczenia, w których argumentacja sądu pokrywała się z przedstawioną w innym orzeczeniu. Zanim jednak przejdę do omówienia wyników przeprowadzonej analizy, chciałabym omówić definicje kluczowych pojęć - honoru i społeczeństwa honoru.

7 Ibidem, s. 123-124. Taka koncepcja może być rozpatrywana w kategoriach kolonizacji i jurydyzacji świata życia (J. Habermas, Teoria działania komunikacyjnego, t. 2: Przyczynek do krytyki rozumu funkcjonalnego, tłum. A. Kaniowski, Warszawa 2002).

8 J. Janssen, op. cit., s. 27. Peter Berger uważa z kolei, że nadrzędna rola honoru jest typowa dla tradycyjnych społeczności, cechujących się hierarchizacją i powiązaniem tożsamości jednostki z ściśle wyznaczona, instytucjonalną rolą w hierarchii. W tym ujęciu honor traci na znaczeniu w tych społecznościach, które oparte są na wolności i równości jednostek. Szerzej: P. Berger, On the obsolescence of the concept of honor, „European Journal of Sociology” 11(2), 1970, s. 339-347.

${ }_{9} \mathrm{Na}$ możliwość powoływania się przez strony postępowań sądowych na działanie w obronie naruszonego honoru w kontekście potencjalności uznania tej motywacji przez sędziów za okoliczność łagodząca wymiar kary, pomimo braku takiej przesłanki w obowiązującym prawie, zwrócił uwage Peter Berger: idem, op. cit., s. 339.

10 Źródło: Portal Orzeczeń Sądów Powszechnych, System Informacji Prawnej Lex. 


\section{DEFINICJE KLUCZOWYCH POJĘĆ}

W literaturze naukowej można odnaleźć wiele definicji i opisów znaczenia pojęcia honoru ${ }^{11}$. Co do zasady definicje te można podzielić na dwie główne kategorie: 1) ukazujące honor w sposób uniwersalny, niezrelatywizowany do określonej płci, jako odbicie opinii innych o jednostce lub jako wyraz przeżyć psychicznych, a także 2) ukazujące honor w kontekście ról społecznych, jako przejaw nierówności płci.

Autorem wpisującym się w pierwszy nurt definicji jest Mark Cooney, który opisał honor przez wskazanie jego 10 głównych cech, stwierdzając m.in., że honor jest takim systemem moralnym, w którym reputacja - rozumiana jako opinia innych o jednostce - jest szczególną wartością ${ }^{12}$. Julian Pitt-Rivers, zwracając uwagę zarówno na wewnętrzny, jak i zewnętrzny aspekt honoru, przez omawiane pojęcie rozumie wartość człowieka w jego własnych oczach oraz w oczach społeczeństwa, jednocześnie ukazuje honor jako swoisty stosunek zobowiązaniowy - przyznający jednostce zarówno roszczenie (ang. claim), jak i prawo (ang. right) do dumy i godności, uznane i respektowane przez świat zewnętrzny ${ }^{13}$. Podobne stanowisko zajęła Janine Janssen, za Yücel Yeşilgöz i Sadikiem Harchaoui wyróżniając honor zewnętrzny (ang. external, rozumiany jako status, reputacja) i wewnętrzny (ang. internal - integralność, duma, cnotliwość). W tym ujęciu honor zewnętrzny jest jednocześnie społecznym uznaniem honoru wewnętrznego jednostki, odzwierciedlonego w jej honorowym zachowaniu ${ }^{14}$.

W drugiej z omawianych kategorii znaczenie honoru, a często sama możliwość cechowania się nim, są zrelatywizowane do określonej płci. Pisząc o przemocy „honorowej” wśród społeczności kurdyjskich, Joanne Payton wyróżnia honor „kobiecy” - namus, tłumaczony jako posłuszeństwo, oraz męski - sharaf, czyli pewność siebie, dominacja ${ }^{15}$. Inni autorzy łączą namus z czystościa i niewinnością, a sharaf z prestiżem, szacunkiem i statusem ${ }^{16}$. $Z$ podziału honoru na honor „kobiecy” i „męski” wynika zróżnicowanie wzorców dobrego „honorowego" - postępowania, płynących z tzw. kodów honoru, w zależności od płci i związanej z tym roli społecznej. Dalsze przykłady kategoryzacji honoru

11 Poza koncepcjami omówionymi poniżej, warto zaznaczyć, że rozważania na temat honoru można odnaleźć w pracach takich autorów, jak Max Weber (soziale Ehre) czy Pierre Bourdieu (M. Weber, Gospodarka i społeczeństwo, tłum. D. Lachowska, Warszawa 2002; P. Bourdieu, Męska dominacja, tłum. L. Kopciewicz, Warszawa 2004).

12 M. Cooney, op. cit., s. 131.

13 J. Pitt-Rivers, Honour and social status, w: J. Peristiany (ed.), Honour and Shame: The Values of Mediterranean Society, UChicago Press, Chicago 1966, s. 21.

14 J. Janssen, op. cit., s. 36, za: Y. Yeşilgöz, S. Harchaoui, Eer voor beginners, w: F. Bovenkerk, M. Komen, Y. Yeşilgöz (ed.), Multiculturaliteit in de strafrechtspleging, Haga 2003, s. 62. Podobne rozumienie honoru można odnaleźć również w pracach innych autorów, m.in.: F.H. Stewart, Honor, UChicago Press, Chicago 1994, s. 12.

${ }^{15}$ J. Payton, Collective crimes, collective victims. A case study of the murder of Banaz Mahmod, w: M.M. Idriss, T. Abbas (eds.), op. cit., s. 69.

${ }^{16}$ C. van Eck, Purified by Blood: Honour Killings amongst Turks in the Netherlands, Amsterdam University Press, Amsterdam 2003. 
w zależności od płci można odnaleźć m.in. w rozważaniach na temat machis$m o^{17}$ czy $i z z a t^{18}$.

Drugie z omawianych pojęć - „społeczeństwo honoru” - jest rozumiane w różny sposób. Zdaniem Aishy Gill przez społeczeństwa bazujące na honorze należy rozumieć takie patriarchalne społeczności, w których działanie w celu ochrony honoru stanowi mechanizm kontrolowania kobiet i dziewcząt, których zachowanie, w szczególności skromność i czystość, staje się komponentem honoru zbiorowości (rodziny, klanu, całej społeczności) ${ }^{19}$. Takie rozumienie społeczeństw honoru jest jednak bardzo etnocentryczne i wynika z określonego ujęcia honoru jako narzędzia kontroli kobiecego zachowania ${ }^{20}$.

Anthony Appiah opisuje „światy honoru” znacznie szerzej, wskazując, że aby rozstrzygnąć, czy dana zbiorowość przywiązuje szczególną wagę do honoru, należy zwrócić uwagę na dwie rzeczy: najpierw trzeba przeanalizować, czy w danej zbiorowości każdy ma prawo do bycia traktowanym z szacunkiem (ang. respect), po drugie - na czym oparte jest prawo do bycia szanowanym. Jeżeli jest to zbiór współdzielonych norm i wartości, możemy mówić o obowiązywaniu kodeksu honorowego postępowania. W takim ujęciu honor jest utożsamiany z prawem do szacunku na podstawie zachowania zgodnego ze współdzielonym zbiorem norm i wartości ${ }^{21}$. Opisane ujęcie honoru jest bardzo uniwersalne i nieograniczone do określonych grup etnicznych czy narodowych, jednakże wymaga każdorazowej, zrelatywizowanej do badanej grupy operacjonalizacji takich pojęć, jak ,prawo do bycia szanowanym”.

Niezależnie od przyjętej definicji kultury honoru, z analizy przedstawionych powyżej stanowisk można wyprowadzić wniosek, że sposób ujęcia społeczeństw honoru - albo jako fenomenu ograniczonego do określonych grup, albo jako pojęcia bardziej uniwersalnego - jest ściśle powiązany z rozumieniem samego honoru. $\mathrm{Z}$ tego właśnie względu wszelkie badania nad zasadnościa przeciwstawiania „kultur honoru” „kulturom prawa” na podstawie prostej opozycji między prawem a honorem na przykładzie Polski powinny zostać poprzedzone omówieniem kwestii podstawowej - rozstrzygnięciem, czy w polskim prawie w ogóle występuje pojęcie honoru, a jeżeli tak, to $\mathrm{w}$ jakim znaczeniu i w jakim kontekście. Z przyczyn wskazanych powyżej analiza tej kwestii została ograniczona do wybranych orzeczeń polskich sądów.

${ }^{17}$ Machismo - zjawisko występujące głównie w krajach Ameryki Południowej i w rejonie Morza Śródziemnego, jest postawą utożsamianą z męskością i honorem. Szerzej: D. Gilmore (ed.), Honor and Shame and the Unity of the Mediterranean, American Anthropological Association 140, Washington, DC, 1987.

${ }_{18}$ Określenie tłumaczone jako honor, stosowane m.in. w Pakistanie. Szerzej: Z. Latif, The silencing of women from the Pakistani Muslim Mirpuri community in violent relationships, w: M.M. Idriss, T. Abbas (eds.), op. cit., s. 34-36.

19 A. Gill, Reconfiguring..., s. 220.

${ }^{20}$ Idem, Introduction: 'Honour' and 'Honour'-Based Violence: Challenging Common Assumptions, w: A.K. Gill, C. Strange, K. Roberts (eds.), 'Honour' Killing \& Violence: Theory, Policy and Practice, Palgrave Macmillan, Basingstoke 2014, s. 2.

${ }^{21}$ A. Appiah, op. cit. 


\section{ANALIZA ORZECZEŃ POLSKICH SĄDÓW}

Na podstawie przeprowadzonej analizy wybrane orzeczenia polskich sadów, odnoszace się do różnie rozumianego honoru, można podzielić na trzy główne kategorie. Pierwsza z nich obejmuje orzeczenia dotyczace honoru służby (zawodu), wykonywanej przez funkcjonariusza publicznego, druga - przypadków przemocy popełnianej w obronie honoru, a trzecia spraw, w których źródłem roszczenia jest naruszenie honoru, zaliczonego do katalogu dóbr osobistych, objętych ochroną prawną na mocy prawa cywilnego lub karnego.

\section{Honor służby (zawodu)}

Pierwsza z kategorii dotyczy spraw, w których centralnym zagadnieniem będącym przedmiotem wyroku było takie zachowanie strony procesowej, które stanowiło naruszenie „honoru służby (zawodu)” i w efekcie prowadziło do wymierzenia określonej kary dyscyplinarnej. Przykładowo w sprawie zakończonej wyrokiem Naczelnego Sąu Administracyjnego w Warszawie z 10 marca 2016 r. (I OSK 3222/14), funkcjonariusz policji został wydalony ze służby za prowadzenie samochodu pod wpływem alkoholu. Skarżący domagał się rewizji kary dyscyplinarnej, uznając ją za niewspółmierną do popełnionego czynu. NSA oddalił skargę kasacyjna, przychylając się do argumentacji organu wymierzającego karę, zgodnie z którą skarżący „swoim zachowaniem naruszył godność i honor służby oraz obowiązujący porządek prawny, których to wartości zobowiązał się strzec, składając ślubowanie"22.

$\mathrm{Z}$ analizy uzasadnienia innego orzeczenia ${ }^{23}$ można wysunać wniosek, że elementem etyki zawodowej policjanta jest honorowe zachowanie zarówno w czasie służby, jak i poza nia. W omawianej sprawie policjanci wzięli udział $\mathrm{w}$ spotkaniu towarzyskim, połączonym ze spożywaniem alkoholu, w siedzibie komendy policji. Zdjęcia z tego spotkania zostały ujawnione przez media. Skarżącemu - jednemu z uczestników imprezy - została wymierzona kara dyscyplinarna ostrzeżenia o niepełnej przydatności dla służby na zajmowanym stanowisku. Skarżący domagał się odstapienia od wymierzenia tej kary, podnosząc, że ,jedyną osoba, która naruszyła honor, godność i dobre imię służby, jest osoba, która przekazała zdjęcia mediom"24. WSA nie przychylił się do tej argumentacji i oddalił skargę, stwierdzając, że wymierzona kara była adekwatna do popełnionego czynu, który stanowił naruszenie honoru, godności i dobrego imienia służby, a „charakter stosunku służbowego policjanta, polegający na szczególnym podporządkowaniu, oznacza, iż przewinienie dyscyplinarne można popełnić także poza godzinami służby" ${ }^{25}$.

Przewinienie dyscyplinarne polegające na naruszeniu honoru, dobrego imienia i godności służby może zostać popełnione nie tylko przez policjantów,

\footnotetext{
${ }^{22}$ Wyrok NSA z 10 marca 2016 r., I OSK 3222/14.

${ }^{23}$ Wyrok WSA w Łodzi z 10 lutego 2015 r., III SA/Łd 1038/14.

${ }^{24}$ Ibidem.

${ }^{25}$ Ibidem.
} 
ale również przez innych funkcjonariuszy publicznych. Dla przykładu, zachowaniem stanowiącym takie przewinienie według orzecznictwa sądów jest przemyt alkoholu bez opłaconej akcyzy przez celnika ${ }^{26}$, podrobienie podpisu współwłaściciela na umowie sprzedaży samochodu osobowego przez żołnie$\mathrm{rza}^{27}$, nieprawidłowe zachowanie w czasie zwolnienia lekarskiego przez funkcjonariusza więziennego ${ }^{28}$.

Na podstawie analizy omówionych orzeczeń sądowych można wyprowadzić wniosek, że w przypadku funkcjonariuszy publicznych honor jest wyznacznikiem określonych wzorców postępowania, których naruszenie może prowadzić do braku możliwości wykonywania określonego zawodu, a także elementem treści norm etyki zawodowej. Te szczególne wymogi odnośnie do właściwego postępowania wynikają z roli społecznej osób pełniących funkcje publiczne i stanowią podstawę autorytetu reprezentowanych przez nie instytucji ${ }^{29}$. Co więcej, wymóg honorowego zachowania wychodzi niejako poza ramy wykonywanego zawodu, obowiązując zarówno w tracie, jak i poza służba.

Wskazanie sprecyzowanych wzorców honorowego zachowania jest trudne, ponieważ „wymogi te wynikają przecież nie tylko ze specyficznych uregulowań ustawowych i z zasad etyki zawodowej [...], ale również z norm etycznych o charakterze ogólnym, z odniesienia sposobu pełnienia urzędu do wymogów wynikających z pojęć o charakterze niedefiniowalnym, jak przyzwoitość, honor czy uczciwość”30. Cytowane orzeczenie Sądu Najwyższego dotyczy godności urzędu prokuratora, jednakże rozważania w nim zawarte można odnieść do innych zawodów wykonywanych przez osoby pełniące funkcje publiczne. W tym ujęciu honor jest pojęciem niedefiniowalnym w sposób szczegółowy, a wzorzec właściwego - a zatem i honorowego postępowania - powinien być każdorazowo zrelatywizowany do konkretnych okoliczności sprawy.

\section{Przemoc w obronie honoru}

Druga kategoria spraw obejmuje przypadki przemocy popełnianej „w obronie honoru"31. Co do zasady taka motywacja działania nie jest uznawana za przesłankę uzasadniająca niższy wymiar kary. Przykładowo w sprawie toczącej się przed Sądem Rejonowym w Środzie Śląskiej, II Wydział Karny ${ }^{32}$ (II K 485/15), sprawca pobicia, skutkującego rozstrojem zdrowia trwającym powyżej siedmiu dni, motywował swoje zachowanie działaniem „w obronie honoru dziewczyny” ${ }^{33}$. Sąd stwierdził, że „nie dopatrzył się w zachowaniu T. D. [sprawcy] jakichkolwiek okoliczności, które wyłączałyby bezprawność jego za-

${ }^{26}$ Wyrok WSA w Krakowie z 16 września 2010 r., III SA/Kr 1159/09.

${ }^{27}$ Wyrok NSA z 1 marca 2007 r., I OSK 788/06.

${ }^{28}$ Wyrok SR w Człuchowie, IV Wydział Pracy, z 11 sierpnia 2016 r., IV P 153/15.

${ }^{29}$ Postanowienie SN z 27 lipca 2016 r., SDI 6/16.

${ }^{30}$ Ibidem.

${ }^{31}$ Sformułowanie zaczerpnięte z omawianych orzeczeń, używane przez sąd, obrońców lub sprawców.

${ }^{32}$ Wyrok SR w Środzie Śląskiej, II Wydział Karny, z 19 stycznia 2016 r., II K 485/15.

${ }^{33}$ Motywacja wskazana przez samego sprawcę. 
chowania czy też zawinienie. W szczególności nie stanowi takiego faktu podana przez oskarżonego w apelacji motywacja [...]"34.

$\mathrm{W}$ innej sprawie sprawca skazany za usiłowanie zabójstwa z użyciem noża motywował swoje zachowanie w następujący sposób: „Nie chciał być dalej przez niego [ofiarę] upokarzany, chciał chronić swój honor i pragną jedynie wyjaśnić istniejące między nimi nieporozumienia" ${ }^{35}$. Tłumaczył jednak, że nie działał z zamiarem zabicia poszkodowanego. Podobnie jak w poprzednim z omawianych orzeczeń, również w tej sprawie sąd nie uznał motywacji działania sprawcy chęcia obrony lub odzyskania honoru za okoliczność uzasadniająca łagodniejszy wymiar kary. Wręcz przeciwnie, sąd uznał, że działanie sprawcy było zaplanowane i kierowane chęcia pozbawienia poszkodowanego życia, a w sprawie nie zaistniały żadne okoliczności wyłączające winę sprawcy.

W orzecznictwie można jednak odnaleźć również takie sprawy, w których sąd uznawał motywację sprawcy działajacego w celu obrony własnego honoru za okoliczność łagodząca wymiar kary. Przykładowo w uzasadnieniu wyroku w sprawie o sygnaturze VI K 614/14 ${ }^{36}$ Sąd Rejonowy w Świdnicy uznał, że poszkodowany, obrażając i wyzywając oskarżonego, przyczynił się do eskalacji konfliktu i sprowokował oskarżonego do zastosowania wobec poszkodowanego przemocy, skutkujacej średnim uszczerbkiem na zdrowiu. Jednocześnie SR stwierdził, że „oskarżony działając w taki, a nie inny sposób, broniąc swego honoru, chciał w gruncie rzeczy jedynie pokazać, że to on - z racji wieku - powinien wieść dominująca w takim - nastoletnim - środowisku rolę" ${ }^{37}$. Na uwagę zasługuje fakt, że to SR podkreślił, że oskarżony działał w obronie swojego honoru, dodatkowo legitymizując omawianą motywację. Sprawa zakończyła się warunkowym umorzeniem postępowania.

Co ciekawe, na podstawie przeprowadzonej analizy można wskazać takie sprawy, w których reakcja na rzekome naruszenie honoru była jedynie następczo przyjęta linią obrony, a nie faktyczną motywacją sprawców. Dla przykładu w sprawie o sygnaturze III K 142/14 ${ }^{38}$, toczącej się przed Sądem Okręgowym w Białymstoku, oskarżeni usiłowali powołać się na prowokację ze strony poszkodowanych, jednakże Sąd nie dał im wiary - okoliczności sprawy predestynuja „do wniosku, że stwierdzenia P. D. [oskarżonego], iż doszło do nieporozumienia spowodowanego przekonaniem, że Czeczeńcy się z nich śmieja, to tylko wybieg. Wpierw mający na celu zakończenie bardzo niezręcznej dla mieniących się silniejszymi (i przede wszystkim lepszymi) od azjatyckich narodów byłego ZSRR oskarżonego i jego kompana, mający niejako uratować ich honor, że sprowokowali zajście, podczas którego zostali pobici. Później natomiast jako przyjęta linia obrony"39. Mimo że stosowanie takiej linii obrony

\footnotetext{
${ }^{34}$ Ibidem.

${ }^{35}$ Wyrok SO w Lublinie, IV Wydział Karny, z 4 lipca 2014 r., IV K 12/14.

${ }^{36}$ Wyrok SR w Świdnicy, VI Wydział Karny, z 22 stycznia 2015 r., VI K 614/14.

${ }^{37}$ Ibidem.

${ }^{38}$ Wyrok SO w Białymstoku, III Wydział Karny, z 26 stycznia 2015 r., III K 142/14.

${ }^{39}$ Ibidem.
} 
mogłoby świadczyć o tym, że posługujący się nią sprawcy antycypowali prohonorowe podejście sądów, w żadnej z przytoczonych spraw motywacja działania sprawców przywróceniem utraconego honoru nie przyniosła pożądanego przez nich skutku - niższego wymiaru kary.

\section{Honor jako dobro osobiste}

Trzecia kategoria spraw, odwołujacych się do pojęcia honoru, obejmuje takie orzeczenia, w których różnie rozumiany honor jest postrzegany jako dobro osobiste, podlegajace ochronie cywilno- lub karnoprawnej w przypadku jego bezprawnego naruszenia.

Dla przykładu, w wyroku z 17 marca 2015 r. Sąd Apelacyjny w Warszawie uznał, że „cześć i honor mieszczą się w pojęciu dobrego imienia” ${ }^{40}$. Przedmiotem sprawy było ujawnienie nazwiska powoda w czasie programu telewizyjnego jako osoby, przeciwko której toczyło się postępowanie karne, niezakończone w momencie emisji. Zdaniem SA wyemitowany program naruszałby dobre imię w sytuacji, gdyby powód został uniewinniony od zarzuconych mu czynów. Postępowanie karne co do części z ujawnionych w programie zarzutów zakończyło się jednak warunkowym umorzeniem, a zatem przesądzeniem o winie i fakcie popełnienia zarzucanego powodowi czynu. Wyeliminowało to bezprawność czynu w odniesieniu do tych kwestii. Ostatecznie o braku bezprawności naruszenia dobrego imienia powoda, a tym samym o oddaleniu powództwa, zadecydowało to, że wykorzystany w programie materiał został zebrany w sposób staranny i rzetelny, w obronie społecznie uzasadnionego interesu (którym było ostrzeżenie przed działalnością powoda, polegająca na pochodnym udzielaniu niezabezpieczonych należycie pożyczek).

Bezprawność naruszenia honoru jako dobra osobistego wyłącza również dozwolona krytyka. Prawo do krytyki nie jest jednak nieograniczone - „krytyka polityczna może być bezkompromisowa i ostra w formie, jednakże musi być rzetelna, ma odwoływać się do faktów prawdziwych, a krytyczne opinie maja mieć umocowanie w faktach. Do przeprowadzenia takiej krytyki oponent winien być przygotowany merytorycznie - jeśli zaś nie ma należytej wiedzy o faktach, winien ważyć słowa"41. Zdaniem Sąu Apelacyjnego w Krakowie wspomniane wymogi nie zostały spełnione w sprawie ${ }^{42}$, której przedmiotem było naruszenie dóbr osobistych: prawa do czci, honoru i dobrego imienia przez pomówienie powoda, pełniącego funkcję publiczna, o przywłaszczenie pieniędzy publicznych na cele prywatne, łamanie prawa budowlanego, a także brak szczerości i kultury osobistej. Sąd przychylił się do argumentacji strony powodowej, stwierdzając, że w omawianej sprawie nie może być mowy o dozwolonej krytyce, twierdzenia na temat powoda były bowiem nieprawdziwe, a ich jedynym celem było ukazanie go w negatywnym świetle w oczach lokalnej społeczności.

40 Wyrok SA w Warszawie z 17 marca 2015 r., VI ACa 596/14.

41 Wyrok SA w Krakowie, I Wydział Cywilny, z 24 kwietnia 2013 r., I ACa 294/13.

42 Ibidem. 
W kolejnym z omawianych orzeczeń ${ }^{43}$ honor został ujęty jako wyraz „czci zewnętrznej”. Przedmiotem postępowania było żądanie zasądzenia zadośćuczynienia za naruszenie dobrego imienia powodowej spółki w postaci zarzutu naruszania zasad uczciwej konkurencji oraz bezprawnego oferowania korzyści majątkowych. W uzasadnieniu wyroku sąd stwierdził, że cześć, obejmująca dwa aspekty - cześć „zewnętrzną” oraz „wewnętrzna”, jest jednym z najważniejszych dóbr osobistych, właściwych każdemu człowiekowi. Cześć wewnętrzna to „godność osobista, stanowiąca wyobrażenie jednostki o własnej wartości, z czym łączy się oczekiwanie szacunku ze strony innych ludzi” ${ }^{44}$. Przez cześć zewnętrzną należy rozumieć „dobre imię, dobrą sławę, honor, reputację, opinię, to inaczej wyobrażenie i obraz jednostki w oczach innych" ${ }^{45}$. Dobre imię danej osoby (także osoby prawnej) to jej pozytywny obraz w oczach otoczenia, a oceniając jego naruszenie należy wziąć pod uwagę przede wszystkim reakcję otaczającego społeczeństwa. Skoro tak, w tym ujęciu honor ma wymiar zewnętrzny, opierający się na opinii i wrażeniach innych, a wyobrażenie jednostki o własnej wartości zostało określone mianem godności osobistej. Opisane rozumienie honoru można odnaleźć również $\mathrm{w}$ innych orzeczeniach ${ }^{46}$.

Honor jako wyraz czci, choć bez podziału na różne aspekty, stał się przedmiotem rozważań w wyroku Sądu Okręgowego w Łodzi z 22 czerwca 2015 r. ${ }^{47}$ W opisywanej sprawie powód domagał się zadośćuczynienia za naruszenie jego czci przez posądzenie go w wulgarnych słowach o bycie homoseksualista. Zdaniem Sądu „cześć człowieka, o której mowa w art. 23 k.c.. ${ }^{48}$, powinna być rozumiana jako honor, dobre imię, godność osobista”, a „określenia, których używał pozwany, mówiąc o powodzie, miały charakter uwłaczający dobremu imieniu i czci powoda. Pozwany przedstawiał bowiem powoda - w wulgarnych słowach - jako osobę o właściwościach, które niestety nie są powszechnie aprobowane w polskim społeczeństwie i zwłaszcza w małych społecznościach lokalnych, takich jak ta, w której żyje powód, i narażają osobę, której dotycza, na wykluczenie ze zbiorowości” ${ }^{49}$.

W orzeczeniu z 9 października 2014 r. ${ }^{50}$ Sąd Apelacyjny w Gdańsku wyraził radykalniejsze stanowisko, stwierdzając że „honor, dobra opinia, szacunek nie stanowią odrębnych dóbr osobistych, lecz emanację dobra osobistego w postaci czci człowieka rozumianej jako dobre imię i godność człowieka. Jest tak również dlatego, że mają one odniesienia do środowiska, w jakim funkcjonuje konkretny człowiek, nie są obiektywne i jednakowe dla wszystkich ludzi”.

${ }^{43}$ Wyrok SO w Warszawie, I Wydział Cywilny, z 10 maja 2016 r., I C 690/15.

${ }^{44}$ Ibidem.

${ }^{45}$ Ibidem.

${ }^{46}$ Przykładowo: wyrok SO w Warszawie, I Wydział Cywilny, z 13 września 2016 r., I C 1130/15; wyrok SO w Lublinie, II Wydział Odwoławczy z 19 maja 2016 r., II Ca 113/16; wyrok SO w Gdańsku, XV Wydział Cywilny, z 16 sierpnia 2013 r., XV C 238/13.

${ }^{47}$ Wyrok SO w Łodzi, I Wydział Cywilny, z 22 czerwca 2015 r., I C 1634/14.

${ }^{48}$ Ustawa z 23 kwietnia 1964 r. - Kodeks cywilny, Dz. U. 1964, Nr 16, poz. 93.

${ }^{49}$ Wyrok SO w Łodzi, I Wydział Cywilny, z 22 czerwca 2015 r., I C 1634/14.

${ }^{50}$ Wyrok SA w Gdańsku, I Wydział Cywilny, z 9 października 2014 r., I ACa 310/14. 
Honor jednostki podlega ochronie prawnej nie tylko na gruncie prawa cywilnego, ale i karnego. Przedmiotem sprawy (VII K 96/15 $5^{51}$ ) toczącej się przed Sądem Rejonowym w Opolu było przestępstwo pomówienia w formie kwalifikowanej - przy użyciu środków masowego komunikowania (art. 212 $\S 2$ k.k. ${ }^{52}$ ). Oskarżony w materiałach wyborczych - ulotkach oraz informacjach kolportowanych za pomocą środków masowego komunikowania, w tym w czasie konferencji prasowej, zniesławił poszkodowana przez rozpowszechnianie nieprawdziwych informacji, zgodnie z którymi poszkodowana przyczyniła się do nieprawidłowości finansowych w gminie, odmówiła czynności służbowych zmierzających do naprawy wykrytych nieprawidłowości, a także zwróciła się do urzędników państwowych o podjęcie działań na szkodę wójta i gminy. Zdaniem SR takie działanie przekraczało granice dozwolonej krytyki. Kwalifikowalność czynu popełnionego przy użyciu środków masowego komunikowania wynika z nierówności stron konfliktu - „walczącej o swój honor jednostki ze środkami masowego przekazu, dysponującymi olbrzymim potencjałem perswazyjnego oddziaływania na opinię odbiorców"53.

Przestępstwo zniesławienia, regulowane w art. 212 k.k., polega na pomówieniu osoby (grupy osób, instytucji, osoby prawnej, jednostki organizacyjnej) o takie właściwości lub postępowanie, które moga ja poniżyć w oczach opinii publicznej lub narazić na utratę zaufania, potrzebnego do wykonywania określonego zawodu lub działalności. Podobnym przestępstwem jest znieważenie innej osoby w jej obecności albo pod jej nieobecność, publicznie lub w zamiarze, aby zniewaga do tej osoby dotarła (art. 216 k.k.). Oba przepisy, zarówno w podstawowej, jak i kwalifikowalnej formie, moga stanowić prawny mechanizm ochrony naruszonego honoru (godności, czci, dobrego imienia).

\section{HONOR JEDNOSTKI A HONOR ZBIOROWOŚCI}

Przedstawiona w poprzedniej części artykułu kategoryzacja orzeczeń nie jest jedynym możliwym sposobem podziału analizowanych wyroków. W dotychczas opisanych orzeczeniach honor był ujęty głównie w wymiarze jednostkowym. Nawet jeżeli wspomniane wyroki sądowe ukazywały honor w aspekcie „zewnętrznym”, jako wyraz opinii i wyobrażeń innych, dotyczyły indywidualnego honoru określonej osoby (co do zasady powoda albo strony postępowania karnego). W orzecznictwie polskich sądów można jednak odnaleźć honor w wymiarze kolektywnym - jako honor określonej zbiorowości.

W wyroku Sądu Okręgowego w Krakowie z 25 kwietnia 2016 r. ${ }^{54}$ pojawiło się pojęcie „honoru narodowego”. Powód, były więzień obozu w Auschwitz-Birkenau, domagał się zakazania stronie pozwanej (niemieckiej telewizji, prowa-

\footnotetext{
51 Wyrok SR w Opolu, VII Wydział Karny, z 25 kwietnia 2016 r., VII K 96/15.

52 Ustawa z 6 czerwca 1997 r. - Kodeks karny, Dz. U. 1997, Nr 88, poz. 553.

53 Wyrok SR w Opolu, VII Wydział Karny, z 25 kwietnia 2016 r., VII K 96/15.

${ }_{54}$ Wyrok SO w Krakowie, Wydział I Cywilny, z 25 kwietnia 2016 r., I C 151/14.
} 
dzącej również internetowy portal informacyjny) posługiwania się pojęciami typu „polskie obozy koncentracyjne”, a także nakazanie opublikowania w ogólnopolskich dziennikach oraz na stronie internetowej telewizji oświadczenia o wskazanej treści, obejmującego m.in. stwierdzenie „przepraszamy Pana K. T. [powoda], który był więziony w niemieckim obozie koncentracyjnym, za naruszenie jego dóbr osobistych, w szczególności tożsamości narodowej (poczucia przynależności do Narodu Polskiego) i jego godności narodowej”55. Powód uzasadniał swoje roszczenia tym, że zwrot „polskie obozy koncentracyjne”, zawarty w zapowiedzi do filmu opublikowanej na stronie internetowej pozwanej telewizji, naruszył jego „honor narodowy”. Sąd uznał, że „poczucie przynależności narodowej oraz duma z takiej przynależności mieszczą się w powszechnie i społecznie akceptowanym zestawie wartości, które mogą stanowić ważny element stanu świadomości i uczuć człowieka, a jeśli są wyznawane i kultywowane przez określoną osobę, należy je uznać za jej dobra osobiste podlegające ochronie przewidzianej w art. 23 i 24 k.c." ${ }_{56}$. W uzasadnieniu wyroku nie wyjaśniono ani nie scharakteryzowano „honoru narodowego”, z jego treści jednak można wywnioskować, że należy łączyć to pojęcie z godnością i tożsamością narodowa, rozumiana jako duma i poczucie własnej wartości, wynikające z przynależności do określonego narodu. Skoro tak, „honor narodowy” jest właściwością pewnego zbioru jednostek, wyodrębnionego ze względu na przynależność do określonego narodu.

W innym orzeczeniu ${ }^{57}$ pojawiło się określenie „kultura honoru”. Przedmiotem sprawy było zabójstwo partnerki dokonane przez osobę pochodzaca z Turcji. W przyjętej linii obrony obrońcy powoływali się na silne wzburzenie sprawcy (art. $148 \S 4$ k.k.), spowodowane okolicznościami i rolą honoru - namus - w kulturze tureckiej. Obrońcy zarzucili opinii biegłych pominięcie różnic kulturowych, określonych przez nich mianem „kultury honoru”. Sąd nie przychylił się do argumentacji obrony, stwierdzając, że sam sprawca w swoich zeznaniach pomijał kwestię wpływu honoru na motywację swojego działania. Zdaniem sądu stan silnego wzburzenia w aspekcie wskazanym w art. 148 $\S 4$ k.k. musi być usprawiedliwiony obiektywnymi okolicznościami, a „w sprawie niniejszej o takowym usprawiedliwieniu okolicznościami nie mogłoby być mowy - w polskich warunkach i polskim systemie prawnym, nawet gdyby przyjać stan silnego wzburzenia towarzyszacy działaniom oskarżonego, tzw. kultura honoru, na którą powołują się obrońcy, a nie sam oskarżony, okoliczności takiej nie może stanowić" ${ }^{58}$. Sąd drugiej instancji nie przychylił się również do argumentacji prokuratora, domagającego się wyższej kary ze względu na prewencję generalna, która w tym przypadku miałaby polegać na „odstraszeniu innych osób, pochodzących z innych kręgów kulturowych, charakteryzujących się odmiennym od europejskiego stosunkiem do kobiet"59. Sąd
55 Ibidem.
56 Ibidem.
57 Wyrok SA w Warszawie, II Wydział Karny, z 21 czerwca 2013 r., II AKa 183/13.
58 Ibidem.
59 Ibidem. 
trafnie zauważył, że okoliczności sprawy nie uzasadniaja przyjęcia, iż różnice kulturowe determinowały postępowanie oskarżonego, a „kwestie zazdrości o pokrzywdzona, podobnie jak chęć kontroli nad partnerem, to tego typu postawy, które zdarzają się bez względu na narodowość"

\section{PODSUMOWANIE}

W orzecznictwie polskich sądów można odnaleźć sprawy, których przedmiotem jest honor. Co do zasady analizowane orzeczenia zapadły w sprawach, które można podzielić na trzy główne kategorie: dotyczace naruszenia „honoru służby”, przypadki przemocy w obronie honoru, a także naruszenia honoru jako dobra osobistego.

Przedstawiony podział nie jest jedynym możliwym sposobem kategoryzacji analizowanych orzeczeń. Inne kryteria mogłyby opierać się na indywidualnym albo kolektywnym wymiarze honoru, na wskazaniu uczestnika postępowania sądowego powołujaccego się na honor, podziale spraw ze względu na przychylenie się do argumentacji strony powołującej się na honor lub wręcz przeciwnie - na braku akceptacji takiego stanowiska. Wybrany sposób kategoryzacji w najpełniejszym stopniu pozwala jednak na wskazanie przepisów prawnych potencjalnie lub faktycznie odwołujących się do omawianego pojęcia.

Nawiązując do tej kwestii, analizowane orzeczenia dotyczyły naruszenia przepisów odnoszących się do etyki zawodowej osób wykonujących określone funkcje publiczne (przykładowo: art. 2 ustawy o służbie wojskowej żołnierzy zawodowych $^{61}$, art. 230 ustawy o służbie więziennej ${ }^{62}$, 23 Zasad etyki zawodowej policjanta ${ }^{63}$ ), przepisów dotyczących dóbr osobistych i ich prawnej ochrony (23, 24, 448 k.c., 212 i 216 k.k.), przepisów sankcjonujących określone czyny zabronione na gruncie prawa karnego (np. zabójstwo, pobicie, udział w bójce).

W orzecznictwie panuje duża rozbieżność na temat znaczenia honoru. Prowadzi to do wniosku, że sędziowie najczęściej posługują się własnym, intuicyjnym rozumieniem tego pojęcia. W analizowanych orzeczeniach albo pominięto definicję honoru, w niektórych wprost określając go mianem pojęcia niedefiniowalnego, albo posłużono się pewną formą definicji ostensywnej, wskazując na wybrane cechy pozytywne (lub negatywne) honorowego zachowania. Honor był ukazywany w aspekcie wewnętrznym, jako wyraz poczucia własnej wartości, lub zewnętrznym - jako odbicie opinii innych o jednostce. Co do zasady wskazywano jednak, że ocena, czy w danej sprawie doszło do naruszenia honoru, nie ma charakteru ogólnego i wymaga każdorazowo analizy okoliczności

60 Ibidem.

61 Ustawa z 11 września 2003 r. o służbie wojskowej żołnierzy zawodowych, Dz. U. 2003, Nr 179, poz. 1750 .

62 Ustawa z 9 kwietnia 2010 r. o służbie więziennej, Dz. U. 2010, Nr 79, poz. 523.

63 Zarządzenie nr 805 Komendanta Głównego Policji z 31 grudnia 2003 r. w sprawie „Zasad etyki zawodowej policjanta”, Dz. Urz. KGP 2004, nr 1, poz. 3. 
sprawy. W żadnym z analizowanych orzeczeń sędziowie nie wprowadzili rozróżnienia na honor „kobiecy” i honor „męski”.

Powstaje pytanie, w jakiej mierze posłużenie się pojęciem honoru było zabiegiem jedynie czysto retorycznym, a w jakiej towarzyszyła mu określona intencja aksjonormatywna. W przypadku wyroków odwołujących się do honoru służby (zawodu), honor był ukazywany jako komponent normatywnych wzorców właściwego postępowania (,honorowego" zachowania). W sprawach z drugiej kategorii, obejmujących różne formy przemocy, działanie w jego obronie stanowiło motywację działania sprawców - albo faktyczna, albo przyjętą później jako linia obrony. W większości postępowań sądowych działanie w reakcji na naruszenie honoru uczestnika procesu nie było jednak uznawane przez sędziów za okoliczność uzasadniająca niższy wymiar kary, a w żadnej z nich nie był wyłączna przesłanką łagodniejszej sankcji. Sąd brał pod uwagę również takie okoliczności, jak młody wiek sprawcy czy uprzednia niekaralność. W przypadku spraw dotyczacych naruszenia honoru jako dobra osobistego honor był ukazywany albo jako odrębne dobro osobiste, albo jako emanacja czci, godności lub dobrego imienia, a często jako synonim tych pojęć.

Honor, w przeciwieństwie do czci, nie jest objęty katalogiem dóbr osobistych z art. 23 k.c. Katalog ten jednak nie ma charakteru zamkniętego, możliwe jest zatem jego rozszerzanie o kolejne dobra. Z zaliczenia honoru do kategorii dóbr osobistych wynika szereg dalszych implikacji. Przede wszystkim dobra osobiste sa wartościami uznanymi powszechnie w społeczeństwie i akceptowanymi przez dany system prawny ${ }^{64}$. Zgodnie z tradycyjnym poglądem, dobra osobiste, jako prawa bezwzględne, sa skuteczne erga omnes ${ }^{65}$. Skoro tak, uznanie honoru za dobro osobiste oznacza przyznanie mu szczególnej prawnej ochrony. Ochrona ta nie ma jednak charakteru absolutnego i w konkretnej sytuacji prawnej może ulec ograniczeniu ze względu na konflikt $\mathrm{z}$ innymi, istotniejszymi prawami i interesami ${ }^{66}$. Przykładem takiej sytuacji jest wyłączenie bezprawności naruszenia dobra osobistego np. przez dozwoloną krytykę, dopuszczalną ze względu na wolność słowa.

$\mathrm{Na}$ zakończenie warto zauważyć, że w większości z przeanalizowanych orzeczeń honor nie był elementem treści przepisów, na które powoływały się strony, a ich zastosowanie w konkretnej sprawie wynikało z interpretacji regulacji prawnych przez uczestników postępowań sądowych oraz sędziów. Obserwacja ta, świadcząca o uznaniu i akceptacji honoru jako wartości niezależnie od jego artykulacji w treści przepisu, jest ważnym punktem wyjścia dalszych badań nad rolą i znaczeniem honoru w polskiej kulturze prawnej.

mgr Joanna Ptak-Chmiel

Uniwersytet Jagiellonski

joanna.ptak@doctoral.uj.edu.pl

${ }^{64}$ Z. Radwański, Prawo cywilne - część ogólna, C.H. Beck, Warszawa 2003, s. 156.

${ }^{65} \mathrm{~J}$. Sadomski, Ochrona czci (dobrego imienia) w polskim prawie cywilnym i karnym - analiza porównawcza, w: A. Siemaszko (red.), Stosowanie prawa. Księga jubileuszowa z okazji XX-lecia Instytutu Wymiaru Sprawiedliwości, Wolters Kluwer, Warszawa 2011, s. 116.

${ }^{66}$ Ibidem, s. 118. 


\section{ARE WE A 'SOCIETY OF HONOUR’? RECONSTRUCTION OF THE TERM 'HONOUR' IN SELECTED JUDICIAL DECISIONS OF POLISH COURTS}

\section{Summary}

The existence of honour as a particular value is not unique, restricted to the boundaries of certain states, nationalities or ethnicities only. Yet, a distinction can be found in the literature between so-called 'societies of honour' and 'modernised societies'. It is believed that in 'societies of honour' honour plays a central role in regulating social relations, and in 'modernised societies' based on the rule of law its importance is marginalised. This article is a contribution to the discussion on the adequacy of the discussed division based on the example of Polish society. Due to the fact that an important feature of this distinction is the juxtaposition of law and honour as tools for regulating social relations, the starting point of the analysis of this issue is to answer the question whether the concept of 'honour' exists in Polish law, and if so, how it is defined and in what contexts it appears. Due to the complexity of this issue, the subject of the article was limited to a specific problem - the analysis of selected judgments of Polish courts and the reasons underlying these judgments. The research allowed to identify the provisions of Polish law which refer (or could refer) to honour. Based on the analysis made, it may be stated that both, judges as well as parties to court proceedings, consider honour as a protected, legally accepted value. 